\title{
Female Homeworkers Alienation Under Putting Out System
}

\author{
$1^{\text {st }}$ Anggaunitakiranantika \\ Sociology Department \\ State University of Malang \\ Indonesia \\ anggaunita.fis@um.ac.id
}

\author{
$2^{\text {nd }}$ Theola Zevana Putri \\ Sociology Department \\ State University of Malang \\ Indonesia
}

\begin{abstract}
This research aimed to describe the working of POS house workers and the alienation and bias they suffer. The Putting Out System (POS) workers, also commonly known as home workers, is a type of occupation in the informal sector dominated by women in Indonesia. This research was conducted using qualitative method, where the choosing of informants using purposive sampling method. The research was analyzed using Karl Marx's theory of alienation. Research was conducted in Malang, East Java Province, Indonesia as one of pilot project involving the highest number of POS workers in Indonesia. The informants of this research were 23 women coming from four different house works, who are sequin worker, garlic peeler, dressmaker, and reading stick cutter (a stick used in Qur'an reading). Based on the research results, conclusions about $\mathrm{POS}$ house workers are as follow: a) Indonesian women chose to become POS house worker in order to support their family without having to neglect their domestic duties, b) considering the process of the work, there was imbalance between the number of hours spent for working and the amount of wage obtained by these female house workers, and c) POS house works create alienation against women. Such situation is a condition that they have to accept because they rely on the job that still rare to research in Indonesia. Among the common issues faced by the POS workers in Indonesia is the payment which is below the standard wage and lower compared to the amount of work tackled.
\end{abstract}

Keywords: gender gap, women worker, fishery industries, Pasuruan-Indonesia

\section{INTRODUCTION}

Putting Out System (henceforth will be referred to as POS), a working system in which a worker bulk-labors a certain task for fixed amount of payment, is one of the types of occupations for women in the informal sector which is interesting to study. In Malang, there has been minimum research attention given to this area of employment, both from the government and the academics. According to the information collected from MWPRI (Partner for Indonesian Female House Workers, a social organization), the number of POS house workers in
Malang is estimated to reach thousands. However, Disnakertrans (the Head Office for Manpower and Transmigration) has not officially published such data, including the number of the workers and the spreads.

POS house workers being referred here are not female housemaids, but rather female workers who labor on production processes in different factories and simple home industries from home or off-site the factories or the employer's industry location. In Malang, the type of tasks performed by house workers include peeling raw materials and commodities to be processed further, convectional dressmaking, embroidering cloth pieces for making commodities, multipurpose ribbon making, different types of good packing, and other types of task which can be performed at home by female house workers. It can also be said that the tasks performed are mostly tasks exclusively attributed as woman's skills

Reflecting to this, previous research showed that female house workers are not legally protected by the Indonesian law and regulations. Furthermore, the statistical data revealing the conditions of house workers in Indonesia is still limited. As of today, house workers, both men and women, are not identified in the Statistics for National Manpower (Sakenas). Workers involved in house working sector have never been surveyed so far by industrial surveys or any related authority. Owing to that, Solechan claimed that house workers become invisible to Indonesian regulations and are classified under the informal sector [1].

Similar research also showed that the existence of female house workers is a phenomenon which the society becomes dismissive about. Considering the gender relation attributed to women, female house workers are considered as second class citizen and as inferior to men. Such view flourishes because social and cultural structures growing within the society favor for patriarchal values. As a result, when women enter the public sector, they become segmented to the informal sector, receiving minimum wage without meaningful economical value [2] 
Based on the previous study, the problem suffered by female house workers in Malang is regarding the disproportional wage compared to the working volume. Female house workers performing different types of tasks are often paid far below the standard wage, while the amount of work they perform is very significant and both energy- and time- consuming. A good example for this is a house worker who peels garlic. To peel a kilogram of garlic, a garlic peeler is only paid IDR 1000 and they work on a minimum 20 kilogram bulk-peeling per day. Garlic peelers are required to work quick and in time that in some occasions they often times are helped by other family members or even neighbor in order to be able to earn IDR 20.000/USD 1.20 , which then will be divided with the helpers. In addition to this, the working hours given to these house workers are far shorter compared to the amount of work that often times forces the house workers to work overtime without any compensation from the employers. In addition to this, these female house workers are not provided with social securities, such as health insurance, from their employers or patrons.

The aim of this research is to describe the alienation experienced by female homeworkers working under POS. Research on homeworkers, especially female house workers, emphasizes on the nationality hegemony context, gender relations, female agency in the social-economical sector, and in the eye of the law. This research is supplemented with studies in female house workers given from different perspectives so that this social phenomenon can be seen even more comprehensively.

\section{METHODS}

This is a qualitative research with descriptive approach which uses house workers working in the sub-district of Malang, East Java Province, Indonesia as subjects. There are five subdistrict was chosen as a location for a pilot project which observed house workers working under POS.

The researcher was directly involved in the data collection by conducting interviews and participatory observations. The research also prepared interview guidelines, which would then be written and recorded. The involvement of the researcher was required in order to obtain thorough information through regular visitations to the 23 informants. The informants were chosen by means of purposive sampling, which was started by reaching out to the General Secretary of MWPRI Mrs. Cecilia S, who then connected the researcher to the coordinator of woman workers Mrs. Sri, who helped the researcher to obtain information about house workers working on different house work tasks. Eventually, house worker community which spread in different location but belonged to one locality was found. They were garlic peelers, sequin workers, convection dressmakers, and reading stick cutters (stick used to read Koran). From this group of female house workers, 23 selected informants were obtained to be involved in the research process, which included answering questions and giving truthful information in a way that prevented data redundancy.

The data analysis technique employed in this research was in the form of data triangulation. Data triangulation is a data collection technique which allows researcher to obtain varieties of data source in order to obtain information which is in accordance to the relevant research questions. The data triangulation technique used in this research was source and theory triangulation. The qualitative analysis was conducted by performing data reduction, which was started by collecting the entire data from the sources, sorting, and developing the data into abstraction which is relevant to the focus of research problems. The next stage was categorizing and interpreting the data before make it into the academics reports.

\section{RESUlTS AND DISCUSSION}

\section{A. Homeworkers Working Under Putting Out System (POS) in the Community}

Some people consider that house workers are similar with housemaids or small-scale individual business which is started at home. The definition of house worker working under Putting Out System (POS) as described by the International Labour Organization (ILO) number 177, year 1996 is as follow.

1. The occupation terminologically is an occupation which is performed individually, by men or women, and has characteristics as follow:

a. The task must be performed at home or in other places which are outside the working site or the house of the employer/patron.

b. There is wage given

c. The occupation is in the form of provision of products by means of providing service which is specifically ordered by employers, with no payment for procurement of working tools, raw materials, or other tools used unless the worker has the economical autonomy and independence sufficient to support the worker as independent contractor under the national law, regulations, and court ruling.

2. An individual with a working status which does not fall under the housework sector according to ILO convention, but otherwise chooses to work at home rather than working somewhere else. The characteristics are as follow.
a. Invisibility
b. Legally unidentified type of occupation
c. Working situation and worker-employer or client- patron relation which handicaps one side of the relation because of the non-existent legal contract.

d. Below standard wage 
e. No social security and health insurance

f. During production process, the house workers are charged with procurement cost (procurement of machines, working space, tools, electricity, water, and many others)

g. Indefinite working hours, which is due to the fact that the work is performed at home and is usually done during day to night.

h. No overtime compensation.

i. This occupation allows child labor. This is due to the fact that children can give a helping hand to lessen the duties of the parents, but only performed in short span of time.

\section{B. Marx's Theory on Alienation Applied on Female House Workers}

Karl Marx's theory of alienation seeks to understand the essence of human. Alienation theory is lied on the thought which acknowledges human's productivity. Essentially, in order to survive and meet with their needs, human needs to extort effort by means of working to afford food, house, and clothing. Productivity is human's natural reaction in expressing basic creativity drives. Furthermore, the basic drive is also expressed collectively, meaning that productivity allows human to fulfill their drive while functioning as social being at the same time. Human needs to cooperate in order to survive and fulfill their needs. However, such natural drive is slowly replaced by a system which according to Marx could have been avoided, called capitalism. Marx believes that capitalist communities are the cause of destruction of the existing social system. This is due to the fact that capitalism makes the poor stays poor, while the rich and capital owner can keep on living in luxury.

Capitalist communities also trigger clash of classes between working class or proletarians and capital owners or the bourgeois. The complexity of such relation impacts on the inequality of profit sharing. Marx's economy theory of surplus value posits that despite the hard work extorted by the working class, the effort will not make them wealthy and prosperous [3]. In contrast, capital owners expense only minimally and as a result amass maximally from the labour of the working class. Clearly, Marx's theory gives some sense to the alienation problem which happens due to social problem which roots from the inequality in social categorization where a party exploits the other. Fromm suggested that exploitation is closely related with power, money, and human needs [4]. Marx's alienation is closely related with the concept of capitalism which is shown through the relation between workers involving in industrial production activities and the capital owners. Such relation is considered as an alienation, because the two parties are equally alienated from the very nature of human, while the workers are very dependent on the capital owners. The interaction between the workers and capital owners are merely on the basis of production; the workers are merely the tools used to fulfill the needs of capital owners while receiving only barely minimum as the compensation of their work [5].

Marx categorizes alienation into four types:

1. Productive activity alienation, which means that working activities are determined by capital owners instead of the workers' initiatives. Workers merely follow the instructions of the capital owners. This results in a situation where workers are only given minimum wage.

2. Product alienation, which means workers cannot enjoy the fruits of their own production. This is due to the fact that the products belong to the capitalists. When workers want to enjoy the products, they would have to purchase the products like everyone else.

3. Alienation from social activities involving other workers. Based on Marx's assumption, human needs to cooperate in order to survive. The presence of capitalism alters human relationships, wherein humans cooperate in order to fulfill the needs of capital owners. Workers often times need to compete among each other by maximizing their production output in order to win the heart of the capital owners, which is then used by them to their own advantage. Instead of solving the conflict, the capital owners turn it as a competition between workers.

4. Alienation from their own potentials. Working place is a place where workers involuntarily alter themselves to fit within working environment in order to follow the demands of the capital owners. Conscience is switched off so that the workers cannot express their qualities.

\section{Becoming Female Houseworker: Surviving in Hopes}

According to the data collected from MPWRI (Partner for Indonesian Female House Workers), an NGO which specializes in advocating and protecting female house workers, there are currently 1570 female house workers in Malang, Indonesia. The aim of this research is to clearly illustrate the conditions of house workers working under POS, including their motives in becoming a home worker, working process, wage payment, and the alienation caused by the occupation with putting out system. Below are the findings regarding the informants' motives in becoming a house worker working under POS.

First, Head Office of Manpower and Transmigration (Depnakertrans), the office responsible for manpower in Indonesia, announced that the law regarding manpower is only applicable to workers working in companies which are formally registered to its office. Therefore, workers who are working on unregistered companies, such as home industries, are not protected legally by the law. This shows the partiality of both the legal and social systems against house workers.

The job served as the source of additional income which was essential to keep the household running. Quoted from the 
addition, the payment system required the workers to wait until the job providers could provide the money to pay them. Hardly ever did the informants received the payment money less than a month after the works were completed. Informants claimed that such situation was nothing new for them and that they could not do anything about it because they could not and would not negotiate with their employers. They were worried about losing job because of complaining and asking for the payment to be made. The worries or feeling bad for asking payment was the result of the workers' desperation of keeping the job and hence the obedience.

TABLE I. The ClassificAtion TABle of FeMALE House Workers IN MALANG, INDONESIA

\begin{tabular}{|c|c|c|c|c|c|}
\hline $\begin{array}{c}\text { Type of } \\
\text { House } \\
\text { Work (1) }\end{array}$ & $\begin{array}{c}\text { Task } \\
\text { Volume (2) }\end{array}$ & $\begin{array}{c}\begin{array}{c}\text { Number } \\
\text { of } \\
\text { Workers } \\
(3)\end{array} \\
\end{array}$ & Wage (4) & $\begin{array}{l}\text { Payment } \\
\text { Due (5) }\end{array}$ & $\begin{array}{c}\text { Work } \\
\text { Duration } \\
(6)\end{array}$ \\
\hline $\begin{array}{l}\text { Sequin } \\
\text { worker }\end{array}$ & $\begin{array}{l}2 \text { day/6 } \\
\text { pieces }\end{array}$ & 8 workers & $\begin{array}{l}\text { IDR 5.000,- } \\
\text { /per piece }\end{array}$ & $\begin{array}{l}\text { To be paid } \\
\text { when the } \\
\text { employer is } \\
\text { ready to pay }\end{array}$ & $2-5$ years \\
\hline $\begin{array}{l}\text { Garlic } \\
\text { peeler }\end{array}$ & $\begin{array}{l}\text { 20-100kg } \\
\text { /day }\end{array}$ & $\begin{array}{c}27 \\
\text { workers }\end{array}$ & $\begin{array}{l}\text { IDR1.000, } \\
\text { /per kg }\end{array}$ & $\begin{array}{l}\text { To be paid } \\
\text { when the } \\
\text { employer is } \\
\text { ready to pay }\end{array}$ & $3-5$ years \\
\hline $\begin{array}{l}\text { Convection } \\
\text { clothing } \\
\text { maker }\end{array}$ & $\begin{array}{c}\text { 30pcs /1 } \\
\text { week }\end{array}$ & $\begin{array}{c}19 \\
\text { workers }\end{array}$ & $\begin{array}{l}\text { IDR 3.000,- } \\
\text { /per piece }\end{array}$ & $\begin{array}{l}\text { To be paid } \\
\text { when the } \\
\text { employer is } \\
\text { ready to pay }\end{array}$ & 2-7 years \\
\hline $\begin{array}{l}\text { Convection } \\
\text { dressmaker }\end{array}$ & $\begin{array}{c}\text { 40-50pcs /1 } \\
\text { week }\end{array}$ & $\begin{array}{c}15 \\
\text { workers }\end{array}$ & $\begin{array}{l}\text { IDR 3.000- } \\
\text { IDR 5.500,- } \\
\text { /per piece }\end{array}$ & $\begin{array}{c}\text { To be paid } \\
\text { upon } \\
\text { completing } \\
\text { task }\end{array}$ & 4-9 years \\
\hline $\begin{array}{l}\text { Headscarf } \\
\text { maker }\end{array}$ & $\begin{array}{c}\text { 100-200pcs } \\
\text { /2 days }\end{array}$ & $\begin{array}{c}21 \\
\text { workers }\end{array}$ & $\begin{array}{l}\text { IDR 1.200- } \\
\text { IDR 1.700,- } \\
\text { /per piece }\end{array}$ & $\begin{array}{l}\text { To be paid } \\
\text { when the } \\
\text { employer is } \\
\text { ready to pay }\end{array}$ & 3-7 years \\
\hline $\begin{array}{l}\text { Reading } \\
\text { stick cutter }\end{array}$ & $16 \mathrm{~kg} / 1$ day & $\begin{array}{c}13 \\
\text { workers }\end{array}$ & $\begin{array}{l}\text { IDR 750,- } \\
\text { /per kg }\end{array}$ & $\begin{array}{l}\text { To be paid } \\
\text { when the } \\
\text { employer is } \\
\text { ready to pay }\end{array}$ & $2-5$ years \\
\hline
\end{tabular}

The volume of the work which had to be performed in short period of time, coupled with the problem of payment, made the workers not having the time to socially interact with their peers and surrounding. Based on the observation conducted, some informants were unable to pay attention fully to their children, such as helping with studying or simply preparing dinner for the family. Female house workers whose occupation is dressmaker had limited social interaction, which mainly were attending activities held by local community. Returning home, they would have piles of work awaiting and they eventually would require the helps from other family members to complete the task. In addition, their interaction with the family members was solely in the form of performing compulsory domestic duties which had to be performed between hustling to finish their job. The interactions with the family members were mostly feeding the 
Reflecting on the discussions above, it can be concluded that female house workers were put at the short end on this system. Therefore, using the theory of alienation, the alienation of house workers working under POS can be illustrated as follow.

\section{1) Production Alienation}

This refers to the fact that the activities involved in the production processes are determined by the employers. This results in employers merely follow the orders and directions given by the capital owners. According to the observation, working under such condition, house workers were only given minimum wage which employers considered adequate. House workers followed the rules set by the employers rather than having their own initiatives. In addition to this, lacking of skills and financial pressure caused these female house workers to have no alternative but following the rules set for them. Because the workers needed the money, they were unable to protest the payment system given by the employers. Both the employers and the informants did not communicate unless there were some issues with the work, which hardly occurred. There were informants who did not know their employers as they worked under the supervision of a manager or third-party distributors. An informant, Mrs. Salama, a convection dressmaker, stated that for seven years of being a convection dressmaker, she had never been taught to know the details of clothes being made, causing her to improvise in designing and creating the details of the clothes. If her works did not appeal the employers, she would have to restart the works all over again.

Productivity alienation was one of reasons for the problem in payment system. Informants were forced to follow the system set by the employers. Miss Dewi, a house worker with garlic peeling job, had been working under POS for 4 years. She demanded that her payment be raised by IDR 500/kilograms or 0.035 USD/kilograms from the original payment of IDR $1000 / \mathrm{kg}$ or $0.070 \mathrm{USD} /$ kilograms because in other places the payment for the same task was IDR $1.500 / \mathrm{kg}$ or 0.11 USD/kilograms as per January, 2019. The employer's response was threatening her to replace her with another worker who would not complain. As a result, Miss Dewi and other workers did not dare to complain anymore because of being afraid losing their job.

The same incident related to unfair payment system was experienced by another house worker named Mrs. Madi. Upon completing her 10 kilograms/day garlic peeling task, the employer was not ready to pay her wage. Her payment was then postponed until she made query again. The employer refused to pay her because the employer claimed that she had not completed her task. Such incident reminded the other garlic peeling house workers to always keep record of their peeling tasks as a proof.

\section{2) Product Alienation}

Product alienation suggests that workers are unable to enjoy the products they help producing. The reason for this is that the can be exploited to be the tools to maximize profits. 
The informants stated that being a house worker working products belong to the employers. In order to be able to enjoy the product, the workers would have to make purchase just like everyone else.

According to the interview and the observations, all informants stated that they were unable to afford the products which they help producing. They were treated like consumers and they could only afford the items when they were on sale. This shows that their employers had the power to alienate their workers from the products which they help producing. An example for this is Mrs. Paini, who had been a headscarf maker for 5 years when she was interviewed. In her job, Mrs. Paini explained that she had to prepare the materials herself, instead of getting them from her employer. Headscarf makers like her would only be able to use leftover materials to make blouse, headscarf, or trousers for herself or her family. However, there would be barely enough materials to make the products that the house workers would not have enough left for them.

\section{3) Alienation from Social Activities with Other Working} Colleagues

Reflecting on Marx, human cooperates with each other in order to survive. The emergence of capitalism changes the human relation to become a means to fulfill the needs of capital owners. Workers are forced to compete against each other by increasing their production in order to impress their employers. Capital owners use this situation to benefit themselves, instead of proposing a solution for solving the conflict caused by competitions among workers.

Working partners should build good cooperation. However, as testified by the informants, house workers would have to compete against each other at work. This type of social alienation was shown by the competitions between house workers working within one locality. One of the informant, Miss Siyamah gave her statement for this condition. When she tried to ask for payment promotion to her employer, her fellow stick cutter house workers proposed to lower their price in order not to lose their job.

Furthermore, the informants' responses implied that their tasks limit their presence in social events held in their localities. The interactions they had with their family were merely occasional. They chose to rest after completing their task in order to recuperate for the next tasks given by their employers.

\section{4) Potential Alienation}

According to Marx's terminology, work place alters worker's personality, turning them to be someone else because they have to follow the employers' orders. Conscience is shut down so that workers cannot express their qualities.

This was reflected in the life of female house workers and was supported by the statements from the informants who chose to become house workers working under POS, despite having the potentials to be independent entrepreneur by having skills in sewing, making design for clothes, needling, and cooking. nder POS for years allowed them to perform a job that did not require marketing, making the income fixed and paid monthly and thus could be used to fulfill their daily needs. Based on the observation, it can be concluded that the informants or the female house workers will not be able to become independent entrepreneurs if they do not want to acknowledge and realize that there are many disadvantages that can be caused by remaining to be house workers.

The observation also found out that these female house workers had the support from their family to work independently, but they claimed that they did not have the motivation to quit working as a house worker working under POS and build networks among house workers because they were worried that such action would cause conflict among house workers.

Reflecting on the discussions above, it can be concluded that the informants were at disadvantage because of their unawareness of the alienation caused by their occupation. The informants considered that what they experienced were normal because they needed the job and it is very difficult for involving into workplace for now in Malang, Indonesia that fits to their skills. However so, the informants remained adamant in being house workers working under POS.

\section{CONCLUSION}

Upon conducting the observation, the female house workers found in Malang worked as informal sector workers. The housework tasks were sequin maker, dressmaker, garlic peeler, and stick cutter. Alienation experienced by these female homeworkers could be categorized into four aspect, namely productivity alienation which was shown by the type of work they performed, product alienation which was shown by a condition in which these female house workers were unable to afford the items made by themselves, social relation alienation which was the condition where the female homeworkers were unable to interact with their neighbors and family due to the massive load of work, and potential alienation which was found from the fact that house workers felt that they did not have enough skills and capitals.

\section{REFERENCES}

[1] Solechan, S. (2018). "Perlindungan Homeworker Yang Bekerja Secara Putting Out System" (POS Homeworker Protection), Administrative Law \& Governance Journal, Vol.1 No 4, pp. 386-390. https://doi.org/10.14710/alj.v1i4.386 - 390

[2] Sofiani, T. (2010). "EKSISTENSI PEREMPUAN PEKERJA RUMAHAN DALAM KONSTELASI RELASI GENDER' (Homeworker Existences in Gender Relation Constellation), MUWAZAH, Vol 2 No 1, pp. 197-204. Retrieved from http://ejournal.iainpekalongan.ac.id/index.php/Muwazah/article/view/17 
[3] Arisandi, Herman (2015) Buku Pintar Pemikiran Tokoh-tokoh Sosiologi dari Klasik Sampai Modern (Thoughts of Sociology Figure: From Classic to Modern Era), IRCiSoD, Yogyakarta.

[4] Fromm, Erich (2014) Konsep Manusia Menurut Marx (Human Concept of Marx), Pustaka Belajar, Yogyakarta
[5] Damayanti, Ismi (2010), "Buruh dan Lingkungan Dari Teori Alienasi Marx" (Worker and Environment a Preview from Marx's Allienation Theory), available at https://www.kompasiana.com/ismidamaya/buruhdan-lingkungan-dari-teori-alienasi-marx_55000e118133116619fa7126, (accessed 13 July 2019) 